\title{
Analysis of the interaction of Salmonellas with macrophages from different host species.
}

\author{
P.R. Watson, A.V. Gautier, S.M. Paulin, P.W. Jones, T.S. Wallis
}

\begin{abstract}
Abstrak
Dasar molekuler dari spesifisitas pejamu Salmonella masih belum jelas. Serotip Salmonella dublin, S. choleraesuis dan S. abortusovis memperlihatkan fenotip pejamu spesifik untuk berturut-turut sapi, babi dan domba. Berbeda dengan serotip tersebut, S. typhimurium mempunyai pejamu yang beraneka ragam. Interaksi serotip-serotip tersebut dengan makrofag dari mencit, sapi, babi dan domba telah dibandingkan. Hasil dari interaksi tergantung pada serotip dan jenis hospes tetapi tidak berkorelasi dengan kespesifikan pejamu dari serotip-serotip tersebut. Galur S. dublin dan S. typhimurium menginduksi lebih besar lisis pada makrofag sapi dan babi dibandingkan dengan galur S. choleraesuis. Hal yang sama ditemukan pada makrofag domba jika dibandingkan dengan galur S. choleraesuis dan S. abortusovis. Sebaliknya keempat serotip tersebut menginduksi lisis dari makrofag peritonium mencit pada tingkat yang sebanding. Makrofag sapi, domba dan mencit lebih sensitif daripada makrofag babi untuk dilisis oleh Salmonella. Lisis makrofag tidak berhubungan dengan gambaran karakteristik apoptosis. Dengan mikroskop elektron transmisi tidak terlihat adanya peningkatan gambaran morfologik yang berhubungan dengan apoptosis pada makrofag monolayer terinfeksi. Juga tidak ada peningkatan laddering of DNA yang khas dari sel yang dilisis oleh Salmonella dibandingkan dengan sel monolayer kontrol. Lisis makrofag tidak diperantarai oleh TNF, tetapi memerlukan adanya salmonella ekstrasel hidup. Gangguan sistem sekresi tipe III yang dikode oleh operon inv/spa melenyapkan kemampuan salmonella melisis makrofag. Hasil ini memperlihatkan bahwa interpretasi hasil interaksi Salmonella/makrofag dalam uji protektif gentamisin harus dilakukan dengan hati-hati. Karena makrofag babi lebih resistan terhadap lisis oleh salmonella, persistensi salmonella intrasel serta produksi sitokin pro inflaminatory setelah infeksi oleh galur $\mathrm{S}$. dublin, S. choleraesuis dan S. typhimurium telah kami teliti dan hasilnya akan kami diskusikan.
\end{abstract}

\begin{abstract}
The molecular basis of Salmonella host-specificity remains unclear. The serotypes Salmonella dublin, S. choleraesuis and S. abortusovis show a host specific phenotype for cattle, pigs and sheep respectively. In contrast to these serotypes, S. typhimipium has a broad host range.The interactions of these serotypes with macrophages from mice,cattle, pigs and sheep were compared. The outcome of the interactions was serotype-and host-dependent but did not correlate to the host specific phenotypes of these serotypes. S. dublin and S. typhimurium strains induced greater lysis of both bovine and porcine macrophages than S. choleraesuis strains. Similarly S. dublin and $\mathrm{S}$. typhimurium strains induced greater lysis of ovine macrophages compared with S. choleraesuis and S. abortusovis strains. In contrast all four serotypes induced comparable levels of lysis of murine peritoneal macrophages. Bovine, ovine, and murine macrophages were more sensitive than porcine macrophages to Salmonella induced lysis. Lysis of macrophages was not associated with features characteristic of apoptosis. Infected macrophage monolayers showed no increase in the morphological features associated with apoptosis when examined by transmission electron microscopy. Similarly there was no increase in the characteristic laddering of DNA isolated from cells undergoing Salmonella-induced lysis compared with uninfected control monolayers. Macrophage lysis was not mediated by TNFa, but required the presence of viable extracellular Salmonellas. Disruption of the type III secretion system encoded by the inv/spa operon abolished Salmonella-induced macrophage lysis. These results demonstrate that extreme caution is required when interpreting Salmonella/macrophage interactions in gentamicin protection assays. As porcine macrophages were relatively resistant to Salmonella-induced lysis the intracellular persistance of Salmonella and the production of pro-inflamnatory cytokines was assessed following infection with S. dublin, S. choleraesuis and S. typhimurium strains; the result of these experiments will be discussed.
\end{abstract}

\section{INTRODUCTION}

Macrophages may potentially have a key role in the pathogenesis of enteric and systemic salmonellosis. Their distribution throughout the body and their bac-

Instinute for Animal Health, Compton, Newbury, Berkhire, RG20 7NN. U.K. tericidal properties could influence the successful establishment of a Salmonella infection and their immuno-regulatory properties could influence the host response to Salmonella infections.

There is some evidence implicating persistence of Salmonella within macrophages in serotype-host specificity $1-4$. The aim of this study was to evaluate the interaction of Salmonella and macrophages using 
natural Salmonella serotype and host cell combinations. Therefore, we studied the interaction of $S$. $d u b$ lin and $S$. choleraesuis strains in bovine and porcine macrophages. $S$. dublin is associated with severe disease in calves and $S$. choleraesuis is associated with severe disease in pigs. The outcome of the interaction of Salmonella serotypes with macrophages was assessed with respect to the effect on both the bacteria (persistence) and the macrophage (amount of lysis, mechanism of lysis and production of cytokines).

\section{MATERIALS AND METHODS}

\section{Bacterial strains}

S. dublin strains SD2229 and SD3246 were isolated from cases of salmonellosis in cattle. S. choleraesuis var kunzendorf strains SCSA50 and SCS14/74 were isolated from cases of salmonellosis in pigs.

\section{Preparation of conditioned culture supernatants from macrophages}

Bovine and porcine alveolar macrophages were isolated as described before 5 . Macrophages were seeded into 24 well tissue culture plates at $5 \times 10^{5}$ cells per ml in Dulbecco's modified Eagle's medium and Ham's nutrient mix F-12 containing $10 \%$ FCS and $100 \mathrm{gml}^{-1}$ gentamicin and incubated overnight at $37^{\circ} \mathrm{C}$ in $5 \%$ $\mathrm{CO}_{2}$. Two hours before infection, the culture medium was replaced with DME/F12 medium containing 5\% FCS and no antibiotics. Bacterial cultures were prepared as described above and diluted in DME/F12 medium to give a ratio of infection of 5 bacteria to 1 macrophage. The overgrowth of bacteria in the culture medium of the monolayers incubated for 24 or 48 hours was prevented by washing the monolayers after 1 hour and adding medium containing 5\% FCS and $100 \mathrm{gml}^{-1}$ gentamicin, followed by washing the monolayers after a further hour and adding medium containing 5\% FCS and $10 \mu \mathrm{gml}^{-1}$ gentamicin. After the appropriate incubation time, the monolayers were centrifuged $\left(300 \times \mathrm{g}, 10 \mathrm{~min}, 4^{\circ} \mathrm{C}\right)$ and the culture supernatants, termed conditioned macrophage supernatants, were aliquoted into sterile eppendorf tubes held on ice. The aliquots were stored at $-70^{\circ} \mathrm{C}$ until assay.

Macrophage damage was estimated by measuring the amount of lactate dehydrogenase released by the macrophages into the supernatants using the Cytotox 96 Non-radioactive cytotoxicity assay (Promega,
Madison, USA). The number of bacteria associated with the macrophage monolayers at each of the time points, and also at one hour after infection, was determined by viable count as described previouslys.

\section{Characterisation of DNA from macrophages}

DNA from macrophages was extracted using the method of Zychlinsky et al6. Actinomycin D mannitol $\left(1 \mu \mathrm{gml}^{-1}\right)$ was added as a positive control for apoptosis. Macrophage monolayers were infected at a ratio of infection of 5 bacteria to 1 macrophage. They were either incubated for $3 \mathrm{~h}$ without the addition of gentamicin or 1 hour after infection the monolayers were washed once with prewarmed medium and incubated for a further 18 hours in medium containing 5\% FCS and $100 \mu \mathrm{gml}^{-1}$ gentamicin.

\section{Bioassay for IL-1-like activity}

IL-1-like activity was measured using the A375 cell line, whose growth is inhibited in the presence of human IL-17. Aliquots of the conditioned macrophage supernatants were thawed and serially diluted in 96 well tissue culture plates and $1 \times 10^{4} \mathrm{~A} 375$ cells were added. The assay plates were incubated for 96 hours at $37^{\circ} \mathrm{C}$ in $5 \% \mathrm{CO}_{2}$. Following incubation, the culture medium was removed and the wells were washed once with PBS. The remaining cells were stained with crystal violet stain for $2 \mathrm{~h}$ at room temp and then the excess stain was removed by washing thoroughly with PBS. The amount of retained crystal violet was measured by spectrophotometry using a wavelength of $595 \mathrm{~nm}$ following solubilisation of the crystal violet in $100 \%$ methanol.

\section{Bioassay for IL-6-like activity}

IL-6-like activity was measured using the 7TD 1 cell line, whose growth is dependent on the presence of IL-68. Aliquots of the conditioned macrophage supernatants were thawed and serially diluted in 96 well tissue culture plates and $1 \times 10^{4} 7 \mathrm{TD} 1$ cells were added. The assay plates were incubated for 96 hours at $37^{\circ} \mathrm{C}$ in $5 \% \mathrm{CO}_{2}$. The assay plates were incubated for 72 hours at $37^{\circ} \mathrm{C}$ in an atmosphere of $5 \% \mathrm{CO}_{2}$. Growth of the 7TD1 cells was estimated by measuring DNA synthesis. An aliquot of $\left[{ }^{3} \mathrm{H}\right]$ thymidine containing $0.015 \mathrm{MBq}$ of radioactivity was added to each well at 18 hours before the end of the incubation period. The cells were harvested onto glass fiber filters and incorporation of $\left[{ }^{3} \mathrm{H}\right]$ thymidine into the cells was measured using a betaplate liquid scintillation counter (Wallac, Milton Keynes, U.K.). 


\section{Bioassay for $\mathrm{TNF} \alpha$-like activity}

TNF-like activity was measured using the WEHI 164 clone 13 cell line, which is sensitive to the cytotoxic activity of human TNF'. Aliquots of the conditioned macrophage supernatants were thawed and serially diluted into the 96 well tissue culture plates containing WEHI cell monolayers. The assay plates were incubated for 18 hours at $37^{\circ} \mathrm{C}$ in an atmosphere of $5 \%$ $\mathrm{CO}_{2}$. Following incubation, the remaining cells were stained with crystal violet stain as described for the IL-1 bioassay.

\section{RESULTS}

\section{Salmonella-induced macrophage damage is host- and serotype-dependent}

The relative ability of $S$. dublin and $S$. choleraesuis to damage bovine and porcine alveolar macrophages was determined. Bovine macrophages were more sensitive to Salmonella-induced damage than porcine macrophages. At three hours after infection, bovine macrophages infected with $S$. dublin had released approximately $80-90 \%$ of the intracellular enzyme lactate dehydrogenase (Figure 1). Porcine macrophages did not release $\mathrm{LDH}$ at this time after infection (data not shown). S. dublin induced significantly more damage than $S$. choleraesuis in bovine macrophages during infection for 3 hours. Porcine macrophages infected with $S$. choleraesuis were not damaged significantly more than the uninfected macrophages at any of the three time points. Macrophages infected with S. dublin exhibited some damage at 48 hours, and this

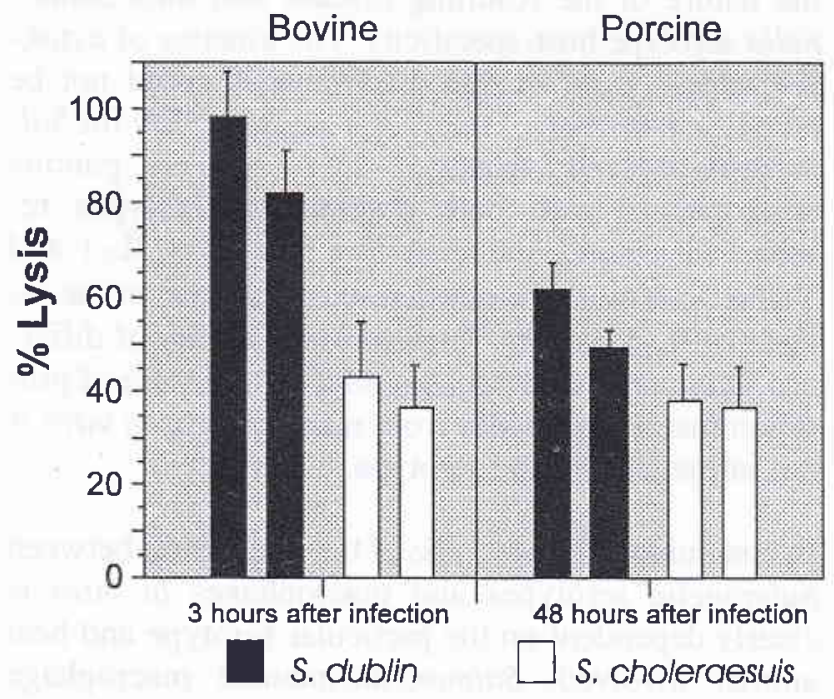

Figure 1. Lysis of alveolar macrophages by $\mathrm{S}$. dublin and $\mathrm{S}$. choleraesuis strains was significantly greater than the $S$. choleraesuis infected macrophages (Figure 1).

\section{Salmonella induce macrophage lysis by oncosis}

The ultrastructure of macrophages after infection with Salmonella serotypes was examined by transmission electron microscopy. In uninfected monolayers of bovine macrophages, the majority of macrophages appeared healthy but there were a minority of cells exhibiting typical features of apoptosis (condensed chromatin located very close to the nuclear membrane together with maintenance of the structure of organelles and membranes). The majority of macrophages incubated with actinomycin D mannitol for 5 hours exhibited typical features of apoptosis. Macrophage monolayers which had been infected with Salmonella serotypes contained cells with a range of morphological changes. Many of the cells appeared necrotic, with a loss of pseudopodia, swollen organelles and condensed chromatin distributed randomly through the nucleus. These changes were more severe at 18 hours after infection and at this time there. was a large amount of debris present, which presumably was a result of macrophage lysis. These ultrastructural changes are more typical of necrosis resulting from oncosis rather than apoptosis. There were more relatively healthy cells in monolayers infected with $S$. choleraesuis compared to those infected with $S$. dublin.

DNA from bovine and porcine macrophages either 3 or $18 \mathrm{~h}$ post infection with either $S$. dublin or S. choleraesuis (with or without the addition of gentamicin) did not show the characteristic DNA laddering pattern characteristic of cells undergoing apoptosis, as was seen with cells treated with actinomycin D mannitol.

Release of pro-inflammatory cytokine-like activity by infected porcine macrophages is independent of Salmonella serotype

Uninfected macrophage monolayers released little IL-1 over the time course of the assay. Macrophages infected with viable bacteria released large amounts of IL- 1 at all three time points of 3,24 and 48 hours. There was no significant difference between the different serotypes.

Uninfected macrophage monolayers released little IL- 6 over the time course of the assay. Macrophages infected with viable bacteria released slightly more IL-6 than the uninfected macrophages at three hours after infection and significantly more IL- 6 at 24 and 
48 hours after infection. Macrophages infected with $S$. choleraesuis released slightly more $\Pi-6$ at 3 and 24 hours after infection than those infected with $S$. dublin, although this difference was not significant.

Uninfected macrophage monolayers released little TNF- $\alpha$ over the time course of the assay. Following infection with all three serotypes, macrophages released large amounts of TNF- $\alpha$ at all three time points. There were no significant differences between the different serotypes ( $p>0.1$ ).

\section{The recovery of Salmonella from infected macro- phages is serotype-dependent}

The number of bacteria associated with the monolayers was determined at the same time points and from the same macrophage preparations that the conditioned macrophage supernatants were collected. The number of bacteria associated with monolayers at 1 hour after infection was also measured to determine whether differences between the serotype could be attributed to the number of bacteria initially taken up. At 1 hour after infection, there was no significant difference in the recovery of $S$. dublin and $S$. choleraesuis. At three hours after infection, $S$. dublin was recovered in higher numbers than $S$. choleraesuis. Thereafter both serotypes persisted within porcine macrophage at comparable rates up to $48 \mathrm{~h}$ post infection.

\section{DISCUSSION}

The aim of this study was to characterise the interaction of $S$. dublin and S. choleraesuis with macrophages from host animals for which the serotypes show differing host-specificty. Salmonella-induced macrophage lysis was dependent on both the serotype and the host. However, macrophage lysis did not correlate to the virulence of each serotype for pigs or cattle. S. dublin induced more macrophage lysis than $S$. choleraesuis in both cattle and pigs, but is associated with severe disease only in cattle. Thus macrophage damage does not correlate to Salmonella serotype-host specificity.

The mechanisms involved in mediating Salmonellainduced macrophage lysis are unclear. Salmonella have been reported to induce lysis of cells by either apoptosis ${ }^{10-11}$ and oncosis 11 . We found no correlation between serotype- and host-dependent macrophage damage and the mechanism of lysis. Primary macrophage cultures were damage by a mechanism resembling oncosis in all serotype and host combinations.
Therefore, the serotype- and host-dependent macrophage lysis appears to be related to the susceptibility of the host cell and to the kinetics of oncosis and not to the involvement of different mechanisms of cell death.

Salmonella serotypes can persist within macrophages in vitro. However, studies which have tried to correlate the persistence of a Salmonella serotype to its virulence in a particular host animal are inconclusive, as failure to control for Salmonella-induced macrophage lysis in vitro when assessing intracellular persistence in a gentamicin protection assay renders the results difficult to interpret. In the present study therefore, the recovery of Salmonella serotypes during macrophage infection was re-evaluated. It was not possible to directly compare the relative ability Salmonella serotypes to survive in bovine or porcine macrophages because of the higher susceptibility of bovine macrophages to be damaged. In porcine macrophages, the persistence of a Salmonella serotype did not correlate to its virulence in pigs. Thus the persistence of Salmonella serotypes in macrophages did not correlate to serotype-host specificity.

Macrophages are important in the regulation of the hosts primary immune response to infection through the release of cytokines and other mediators of inflammation. This response may influence the ability of the host to control infections, but may also exacerbate some aspects of disease. If infection of macrophages with different Salmonella serotypes results in the release of different types or amounts of inflammatory mediators, this could affect the severity and the nature of the resulting disease and thus Salmonella serotype host-specificity. The kinetics of cytokine release from bovine macrophages could not be quantified because of their high susceptibility for $\mathrm{Sal}$ monella-induced damage. Infection of porcine macrophages with both Salmonella serotypes resulted in a rapid and sustained release of IL-1 and TNF $\alpha$ activity and a more gradual increase in the release of IL-6 activity. Therefore, the ability of different Salmonella serotypes to induce the release of proinflammatory cytokines from macrophages in vitro is not influenced by the serotype.

In conclusion, the outcome of the interaction between Salmonella serotypes and macrophages in vitro is clearly dependent on the particular serotype and host animal involved. Salmonella-induced macrophage lysis in vitro means extreme caution is required in interpreting the persistence of salmonellas within 
macrophages in gentamicin protection experiments. The host specificity of $S$. dublin and $S$. choleraesuis for cattle and pigs respectively cannot be explained by any 1 of the following parameters: Salmonella-induced macrophage damage, bacterial uptake or persistence within macrophages, mechanism of macrophage damage or release of pro-inflammatory cytokines by macrophages.

\section{REFERENCES}

1. Vladoianu I-R, HR Chang; J-C Pechère. Expression of host resistance to Salmonella typhi and Salmonella typhimurium: bacterial survival within macrophages of murine and human origin. Microbial Pathog 1990; 8: 83-90.

2. Alpuche-Aranda CM, Berthiaume EP, Mock B, Swanson JA, Miller SI. Spacious phagosome formation within mouse macrophages correlates with Salmonella serotype pathogenicity and host susceptibility. Inf Immun 1995; 63: 445662.

3. Ishibashi Y, Arai T. A possible mechanism for host-specific pathogenesis of Salmonella serovars. Microbial Pathog 1996; 21: $435-46$.

4. Schwan WR, Kopecko DJ. Serovar specific differences in Salmonella survival within macrophage cells. Mechanisms in the Pathogenesis of Enteric Diseases. Ed Paul et al, Plenum Press New York. Chapter 1997; 46: 277-8.
5. Guilloteau LA, Wallis TS, Gautier AV, MacIntyre S, Platt DJ, Lax AJ. The Salmonella virulence plasmid enhances Salmonella-induced lysis of macrophages and influences inflammatory responses. Infect Immun 1996; 64: 3385-93.

6. Zychlinsky A, Prevost MC, Sansonetti PJ. Shigella flexneri induces apoptosis in infected macrophages Nature 1992; 358: 167-8.

7. Nakai S, Mizuno K, Kaneta M, Hirai Y. A simple, sensitive bioassay for the detection of interleukin-1 using human melanoma A375 cell line. Biochem Biophys Res Commun 1988; 154: $1189-96$.

8. Van Snick J, Cayphas S, Vink A, Uyttenhove C, Coulie PG, Rubira MR, Simpson RJ. Purification and NH2-terminal amino acid sequence of a T-cell-derived lymphokine with growth factor activity for B-cell hybridomas. Proc Natl Acad Sci USA 1986; 83: 9679-83.

9. Espevik T, Nissen-Meyer J. A highly sensitive cell line, WEHI 164 clone 13, for measuring cytotoxic factor/tumor necrosis factor from human monocytes. J Immunol Method 1986; 95: 99-105.

10. Monack DM, Raupach B, Hromockyj AE, Falkow S. Salmonella.typhimurium invasion induces apoptosis in infected macrophages. Proc Natl Acad Sci USA 1996; 93: 9833-8.

11. Chen LM, Kaniga K, Galán JE. Salmonella spp. are cytotoxic for cultured macrophages. Mol Microbiol 1996; 21: 1101-15. 